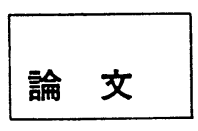

UDC $621.385 .832: 681.6$

\title{
記録針のない静電記 録管
}

\author{
シャープ株式会社 中央研究所田川孝生
}

\begin{abstract}
記録ヘッドに針を使わない新しい動作原理の静電記録管を開発した.この静電記録管は記録へッ ドに厚さ約 $180 \mu \mathrm{m}$ の半導体ガラスを使用したもので, 徒来の記録管にくらべて構造がきわめて簡 単である. 高速記録が可能なので，ファクシミリ，高速度波形記録装置への応用が可能である. 本 文ではこの記録管の構造, 動作原理, 記録ヘッドの材料, 記録結果について述へる.
\end{abstract}

\section{1. ま え がき}

ファクシミリ用高速記録管として，いままでにいろい ろな方式のものが提案されている．乙れらの記録管の代 表的なあののひとつにピンチューブ1)2)がある. ピンチ ユーブはブラウン管のスクリーンに相当する部分に，互 いに絶縁された細い金属ピンを多数貫通させ，ピンを 通 して，電子ビームの走査による電荷を直接管外に導き出 し，管外の静電記録紙上に電荷像として与えるものであ る.

ピンチューブは光を用いずに，電荷による記録を行な うので, 他の光を利用する方式より安洒な静電記録紙が 使えるばかりでなく, 記録装置の記録部, 記録紙を遮光 する必要がないなど，他の記録管にない特長を持って る。しかしながら，記録ヘッドとして，細い金属ピンを 密に植え込まねばならないので，生産性および記録時の 放電による記録へッドの性能低下などの問題を残してい る.

そこで，ピンチューブの特長を生かし，かつ生産性の 面で有利なピンのない静電記録管を開発し，試作管によ る記録実験を行なったので，その結果を述べる.

\section{2. 構造と動作 ${ }^{3)}$}

本記録管は，記録ヘッドを除けば電子銃，偏向コイ ル，電圧印加方法など，すべてピンチューブと同じであ る.管の構造ならびに記録紙との配置関係を図 1 亿示す. ピンチューブの場合は，記録ヘッドとして互いに絶縁さ れた細い金属線を多数植えたピンヘッドを用いるが，本 記録管の記録ヘッドは，わずかに導電性のあるマイクロ

"Electrostatic Printing Tube Dispensed with Embedded Pins" by Takao Tagawa (Central Research Laboratory, Sharp Corporation, Nara)

$768(32)$

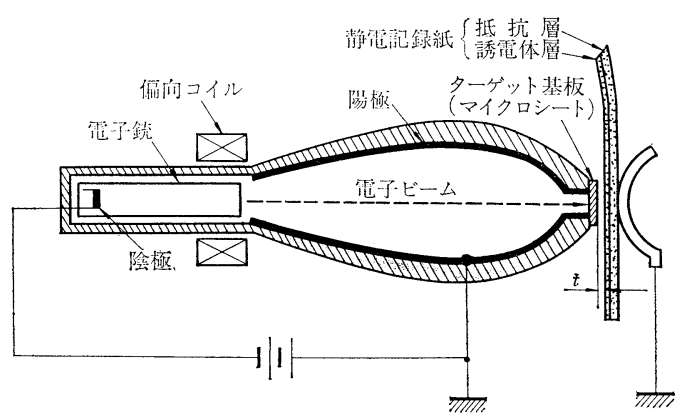

図 1 構 造 図

Cross-sectional view of the Electrostatic Printing Tube.

シート，あるいは適当な抵抗值の物質を薄く塗布した誘 電体のマイクロシートより構成されているにすぎない.

したがって, 構造としてはピンチューブよりむしろ薄空 管に似ている.

この記録管に使われる記録紙は, 数 $\mu \mathrm{m}$ の誘電体層, 数十 $\mu \mathrm{m}$ の抵抗層から成る静電記録紙であって，ピン チューブなどに使われるものと同じである，記録紙とタ ーゲット基板は密着せずに，両者の間に薄い空気層を設 けているまた記録紙の抵抗層は，接地またはそれに近 い電位になっている.

本静電記録管への印加電圧は，図 1 亿示すように負の 高圧を使用し，陽極を接地してカソードに負の高圧（た とえば $-10 \mathrm{kV})$ ，を印加している．したがって，電子ビ ームを照射しないときのターゲットの電位は，ほぼ接地 電位である. 一方，ターゲットを構成している誘電体の 2 次電子放出は，一般に図 2 のような特性を示す. 2 次 電子放出比は数百 $\mathrm{V}$ の点でピーク值を示すが, 以後, 加速エネルギーの増加とともに減少してゆき， $V_{h}$ では 1よりはるかに小さくなる.

それゆえ，とのような特性を持ったターゲットに $V_{h}$ 


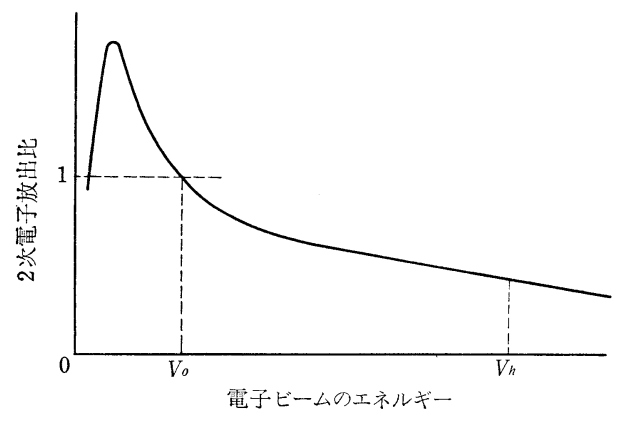

図 2 ターゲットの 2 次電子放射特性

Secondary electron emission ratio from the target.

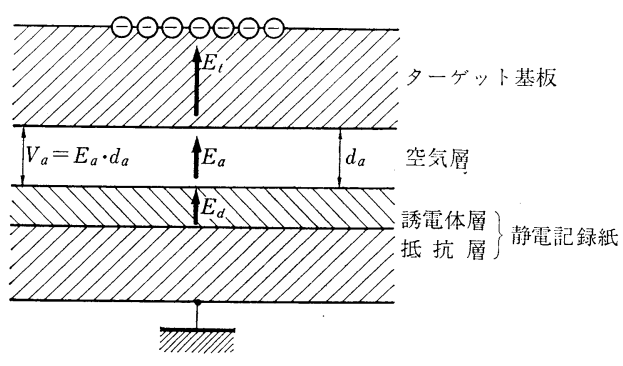

図 3 ターゲットおよび記録紙

Schematic sectional view of target and recording paper.

なるエネルギーの電子ビームを照射すれば，照射点は負 に帯電し，電位は降下する，そのときの記録紙をむ含め たターゲット近辺の様子を図 3 亿示す．記録紙の抵抗層 は接地されているので, ターゲット基板, 空気層, 誘電 体層には，おの拉の図のように $E_{t}, E_{a}, E_{d}$ なる電界が できる

空気層の厚みを $d_{a}$ とすれば，空気層の記録紙側と夕 一ゲット基板間には $V_{a}=E_{a} \cdot d_{a}$ なる電位差を生ずる.

あし，とこで電界 $E_{a}$ (または $V_{a}$ ）が空気層での放電 に必要な值であれば，空気層で放電が起てる．空気層で の放電に必要な電界は図 4 亿示すように層の厚みによっ て異なる4)。すなわち，薄い空気層の場合には，放電に 必要な電界が大きくなり，厚くなるほど小さな電界で放 電を起てさせるととができる，しかし空気層が厚すぎる と，画質などの点で弊害が現わ机るので，最適值は数 $\mu \mathrm{m}$ から $30 \mu \mathrm{m}$ 程度である.

放電は，雪崩現象により空気層に多数のイオンと電子 が発生した状態であり，てこで発生した正負の電荷は, 早い速度で正電荷（陽イオン）は $E_{a}$ の方向に，負電荷

（電子）は $E_{a}$ 之反対方向にそれぞれ移動し，ターゲッ 卜基板の外壁ならびに記録紙の誘電体層上に帯電する.

放電直後のターゲットならびに記録紙における電荷分 布は図 5 のようになっている。この放電によって生じた 記録紙面上の負電荷とターゲット外面上の正電荷によっ

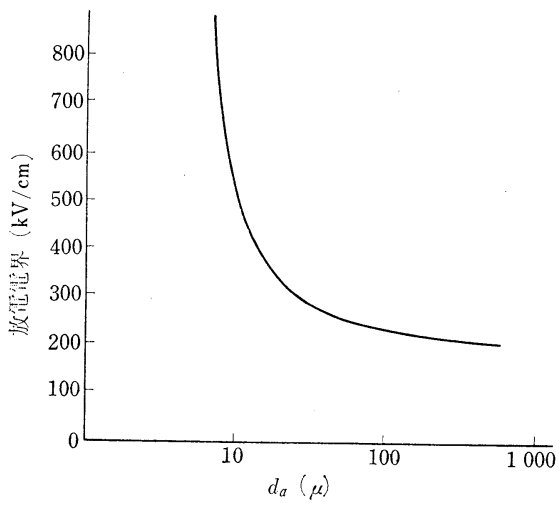

図 4 放電特 性

Relation between the discharging electric field vs air gap.

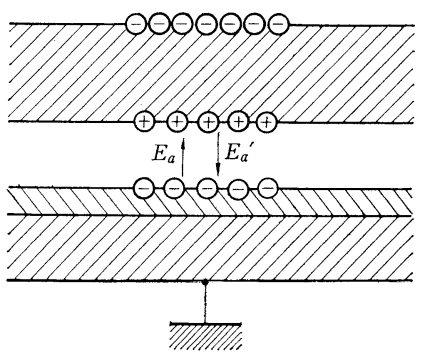

図 5 放電後の電荷分布

Schematic view that shows the distribution of charges on the target and the recording paper immediately after the occurence of discharge.

て，空気層に $E_{a}{ }^{\prime}$ なる電界ができる，乙の電界 $E_{a^{\prime}}{ }^{\prime}$ は ターゲットの負電荷による電界 $E_{a}$ 亡逆向きであるか ら, 空気層の電界は $\left(E_{a}-E_{a}{ }^{\prime}\right)$ 亿減少し，まだターゲ ットに負電荷があるにあかかわらず，放電を持続させる ことができずに，きわめて短時間で停止する.

この放電は, ターゲットの電子ビーム照射点に対応す る空気層で起とる.しかむ, それによって生じた負電荷 は，やはりとれに対応する記録紙の誘電体層上に带電す る. したがって, 映像信号で変調された電子ビームがタ ーゲット上を走査すれば，記録紙上に電荷像が記録され る.

記録終了後のターゲットの負電荷ならびに対向の正電 荷は，次の周期に怙ける記録の妨げになるから，空気層 での放電終了後, すみやかに消滅（放電）させねばなら ない. これらの不要電荷の消滅方法については後で述べ る.

記録紙面に記録された電荷像は，ピンチューブの場合 と同じように，電荷像と逆の電荷を持ったトナ一を用い て可視像に変換する. 


\section{3. 記録に必要なターゲットの電位}

電荷が带電しているターゲット上に微小面積を考え, この微小面積の带電電荷を $Q$ (負の電荷) とし, 微小面 積とアース間の静電容量を $C$ とすれば, 微小面積の電位 $V$ (負) は,

$$
V=\frac{Q}{C}
$$

で与えられる．またての $V$ を図 3 につて考えると， 次式のようになる.

$$
V=E_{t} d_{t}+E_{a} d_{a}+E_{d} d_{d}
$$

(2) 式で $d_{t}, d_{a}, d_{d}$ はターゲット基板, 空気層, 記 録紙の誘電体層の厚みであり, $E_{t} d_{t}, E_{a} d_{a}, E_{d} d_{d}$ は各 層に分割される電位である. $E_{a} d_{a}$ は空気層で放電を起 し，静電記録を行なうために，ある一定值以上必要であ るが， $E_{t} d_{t}$ は静電記録にまったく不要な電位である.

しかしながら，実際の記録管に打いては $d_{t}$ が約 180 $\mu \mathrm{m}, d_{a}, d_{d}$ が数 $\mu \mathrm{m}$ から十数 $\mu \mathrm{m}$ であるから, ターゲ ットの電位 $V$ は空気層電位 $V_{a}$ よりはるかに大きい. ターゲット電位が大きくなると，いろいろ䉼害を生ずる ので, ターゲット基板の誘電率を大きくし，基板を薄く するなどの方法で小さくする必要がある.

実際の記録管について，記録時のターゲットおよび空 気層の電位を測定するととは不可能である.したがっ て，図 6 亿示すような模型により静電記録に必要な電位 を測定し，ほぼての值がターゲット電位になっているも のと考えている゙

誘電体層 (1)はターゲット基板に相当するあので, $150 \mu \mathrm{m}$ のマイクロシートガラスを使用し，その一部に アルミを蒸着して電極 $(1)$ を形成した. 誘電体層 $(2)$ は 静電記録紙の誘電体層に相当するすのである. 市販の静 電記録紙には数 $\mu \mathrm{m}$ の凹凸があり，空気層の厚み $d_{0}$ が 不正確なむのになるので，平面度のすぐれたマイラーに 金属を蒸着したすのを使用した．また印加電圧 $V$ は負 の単発パルスを印加し, 誘電体層 $(2)$ の電荷像形成の有

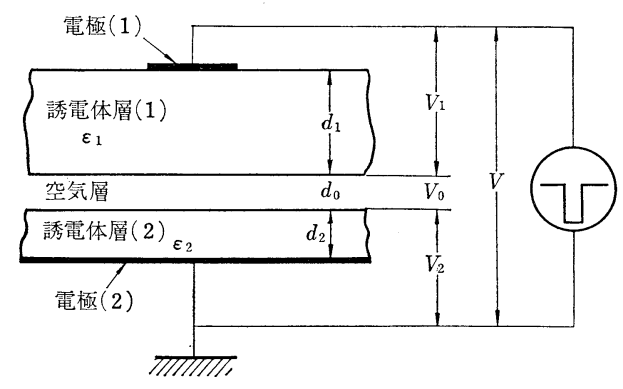

図 6 模型による記録実験 Simulated recording device.

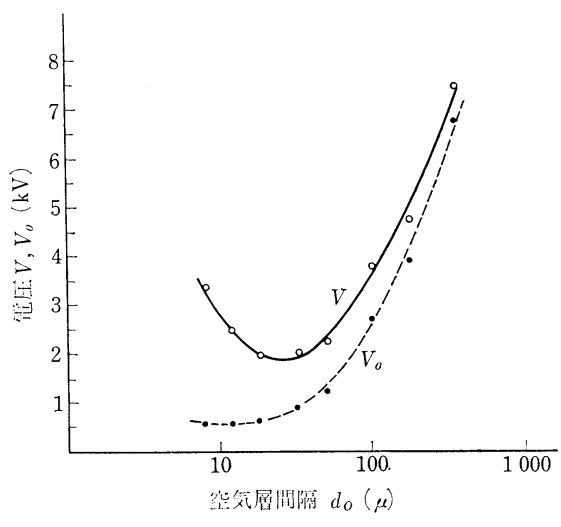

図 7 記録電圧特性

Characteristics of recording voltage vs air gap.

無はトナーで現像して判別した.

空気層の厚み $d_{0}$ を変えた場合の記録に必要な電位 $V$ は図 7 のと抢りである.また, ターゲットの電位 $V$ が $d_{1} / \varepsilon_{0} \varepsilon_{1}, d_{0} / \varepsilon_{0}, d_{2} / \varepsilon_{0} \varepsilon_{2}$ の比で誘電体層 $(1)$, 空気層, 誘 電体層 $(2)$ 亿分割されるすのとして空気層の電位 $V_{0}$ を 算出し, 点線で示した。

静電記録に必要なターゲット電位は $20 \mu \mathrm{m}$ にしたと きに最低を示し，ほぼ $2 \mathrm{kV}$ である，また空気層の電位 $V_{0}$ は $P=760 \mathrm{mmHg}$ としたときのパーシェンの放電特 性に近い值を示しており放電により記録が行なわれるこ とを裏づけるものである.

\section{4. ターゲット基板}

\section{1 ターゲット基板の抵抗}

記録終了後のターゲット基板は図 5 のように正および 負に帯電している．乙のような状態で次の周期の走查を 行なっても記録は行なわれない，電子ビームがターゲッ 卜を走査する際, 先の走査に抢ける電荷がターゲット上 に残っていると，その部分の電位が低くなっているので $(-2 \mathrm{kV}$ 以下), 電子ビームはターゲット上の走查点か らはずれ，電位の高い部分を走查するのが原因のひとつ である、これはターゲット扔よびその近辺を走査する電 子ビームにより発する螢光により確認している.

また先に述べたように，ターゲット基板外表面の正電 荷により, 空気中の電界が弱められるから, 空気層での 放電すなわち記録が行なわれにくくなる.

したがって，てれらの電荷は次の周期における走查ま でに何らかの手段で除去しなければならない，電荷を除 去する手段として，次のような方法が考えられる.

(1) 1 ラインの記録終了後, 低速電子ビームをターゲ ットに照射して，そのときの 2 次電子放出を利用し てターゲット面上の電荷を除去する. 
(2) ターゲット面上に適当な抵抗值を持った抵抗層を 形成し，抵抗層を通してターゲット面上の電荷を除 去する.

(3) ターゲット基板として，わずかに導電性のある材 料を選び，ターゲットの厚み方向に電荷を移動さ せ，両電荷を同時に除去する。

(1)の 2 次電子を利用する方法は，電荷の帯電のみを考 慮してターゲット基板を選べる反面，記録時と電荷の除 去時ではエネルギーの異なる電子ビームを照射しなけれ ばならないので，電子銃，周辺回路が複雑になる。ま た，ターゲットの電荷は除去されるが，ターゲット基板 外表面の正電荷は除去されない.

(2)の方法はターゲット基板として，(1)の場合と同様， マイカ, ホウ硅酸ガラスなど, 抵抗值の高いマイクロシ 一トを使える．マイカ板 $(75 \mu \mathrm{m})$ に酸化クロムと黒鉛 の混合物を塗布した試作管による実験の結果では，記録 に必要なビーム電流が，後に述べる(3)の方法のほほ 10 倍であった. (1)の場合と同様, ターゲット外表面上の正 電荷は除去できない，また薄い抵抗層を均一に塗布する のも㕅難である.

(3)のターゲット基板の導電性を利用する方法は，記録 時のビーム電流量, 記録管の構造などの点で最む有利な 方法であり，実験管はこの方法を採用している．ての方 法で重要なのは, ターゲット基板の誘電率および抵抗值 の設定である．抵抗值が低すぎると電子ビームの電荷を ターゲット上に帯電させることができない，抵抗值の低 い例として，シリコンウエハーをターゲット基板に応用 した実験を試みたが，まったく記録できなかった。

また電荷の帯電からすれば，ターゲット基板の抵抗值 は高いほどで有利であるが，高すぎると記録終了後の不 要電荷の除去が困難になり，先に述べたような理由で記 録ができない，たとえば石英ガラスをターゲット基板に 応用して屯，記録管としてはまったく動作しない。した がって，電荷の带電と放電のかね合いから適当な抵抗值 のターゲット基板を採用しなければならない.

ターゲット基板の内外面に $Q_{0}$ の電荷が帯電している あのとすれば，電荷は時間 $t$ ととあに，

$$
Q=Q_{0} \exp \left(-\frac{t}{\tau}\right)
$$

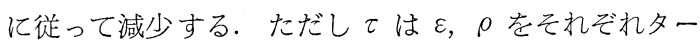
ゲット基板の比誘電率，固有抵抗とした場合， $\tau=\varepsilon_{0} \varepsilon \rho$ で与えられる. それゆえ，電子ビームの走査周期を $T$ とした場合，てとＴとをほぼ同じオーダーになるよう に $\varepsilon, \rho$ を選べば良いすのと推察できる. 走查周波数を $60 \mathrm{~Hz}$ とすれば， $\varepsilon=5$ として， $\fallingdotseq \fallingdotseq 4 \times 10^{8} \Omega \cdot \mathrm{m}$ となる. 詿作管による実験の結果，てうTであればまったく問題
はなくてをを Tの10 倍に選んでも記録にはほとんよ゙ 支障をきたさないてとを確認している. それゆえ $\varepsilon=5$, $\rho=4 \times 10^{8} \Omega \cdot \mathrm{m}$ のターゲット基板を使用した記録管は， ほぼ $600 \mathrm{~Hz}$ までの記録を行なうことができる.

\section{2 ターゲット基板の材料}

ターゲット基板はターゲット执よび記録ヘッドとして の電気的性能（固有抵抗，2次電子放出等）を満足する あのでなければならないととはもちろんであるが，同時 に真空容器の一部であある. しかも非常に薄いことが必 要であるから, 気密性, 機械的強度の点で充分すぐれた むのでなければならない，このような条件をすべて满す 材料を入手するととはきわめて困難であるが，乙れに近 いものに電導性ガラスがある.

ガラスは通常絶縁物として扱われる. 事実, 石英ガラ スのようにアルカリをほとんど含まないガラスでは $10^{15}$ $\Omega \cdot \mathrm{m}$ 以上の抵抗を示す. また，ガラスとしては抵抗值 が低いといわれているソーダガラスであ $10^{11} \Omega \cdot \mathrm{m}$ 上上 である.したがって，てのような抵抗値の高いガラスは 記録管のターゲットに使えない.

抵抗值の低いガラス，すなわち電導性ガラスには，ガ ラス中に含まれるイオンにより伝導性を示すすのと電子 によるものとがある．イオンにより伝導性を示す代表的 なガラスはソーダガラスである.とれはガラスに含まれ る $\mathrm{Na}$ イオンによって主に伝導が行なわれるから，ての ガラスに連続して電流を流しておくと，ガラス内部で電 気分解を起し，抵抗は増大する.すなわち $\mathrm{Na}$ イオンは 徐々に陰極に引き寄せられ，内部の $\mathrm{Na}$ イオンはそれに 伴い減少するために起る現象である，したがって，ての 種のガラスをターゲット基板に使用すると動作中に同様 な現象を起すむのと考えられる. 約 $20 \%$ のソーダを含 むイオン伝導性ガラスをターゲットに使用した記録管の 寿命テストでは，著しい性能劣化が見られた。

一方，鉄，バナジウムなどの遷移金属の酸化物を多量 に含むガラスむ, やはり伝導性を示す. しかし，ての場 合の伝導機構はイオンによるものでなく, 電子によるも のと考えられて抢り, 電子伝導性ガラスまたは半導体力゙ ラスと呼ばれている．電子伝導性ガラスに連続して電流 を流してあ，イオン伝導性ガラスのような抵抗值の変化 はほとんど見られない. 当研究においてはターゲットと して電子伝導性ガラスを使用した．遷移金属としては鉄

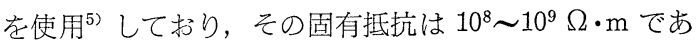
万.

\section{3 記録ヘッドの構造 ${ }^{6)}$}

記録へッド近辺の概略図を図 8 に示す. 記録ヘッドと なる部分は，ターゲット基板の外表面で図のように外部 電極を設けている．外部電極は 2 枚の電極から構成され 


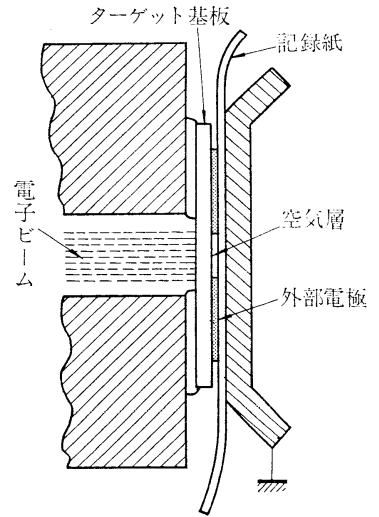

図 8 記録ヘッドの構造図 Cross sectional view of the printing head.

ていて，その間はスリット状に空いている．そして電子 ビームはそのスリットに対向するターゲット基板の内 側，すなわち真空側を線走査する．乙の電極は，電極之 しての作用はもちろんであるが，他にも重要な㗢きをす るむのである.

第1の役割はスペーサーとしての働きである. 先の動 作原理において説明したように，本記録管においては， ターゲット基板と記録紙の間に数 $\mu \mathrm{m}$ の空気層を必要と する．したがって，図８のように記録紙を外部電極に密 着して走行させると，ターゲット基板と記録紙の間には ほぼ外部電極の厚みに等しい空気層を形成できる，空気 層の最適厚みは $8 \mu \mathrm{m}$ 程度であるが，試作管においては 製造上の問題より $5 \mu \mathrm{m}$ 程度にしている.

このような形で空気層を得るととは，同時に記録紙と の摩擦によるターゲット基板の摩耗を少なくする作用む かねるあのである.

第 2 の役割は，ての電極を接地電位にしてノイズ記録 を除去することである. ターゲット基板は電気的に浮い ており，外部電極を設けない場合の電位はきわめて不安 定である，そして，その不安定な電位がある值に達する と，それに面した静電記録紙に電荷が移り，ノイズとし て記録される．外部電極を設け，乙れを接地電位にする ことにより，乙の問題は解決できる.

第 3 の役割は解像度の改良である. 動作原理で説明し たように，この記録管はターゲットに带電した電荷によ って作られる空気層の電界を利用したものであるから， 外部電極の形状により画質を改良することができる.す なわち，電子ビームの直径が $0.5 \mathrm{~mm}$ 程度であっても， スリットの幅を $0.3 \mathrm{~mm}$ にすれば，スリット幅をはずれ る部分の電界はすべて外部電極によって遮蔽され，記録 線の幅はスリット幅より小さくなり，0.2 mm 以下に改 良される。
このように，外部電極に幾つかの目的をかねた重要な 部分である.この電極は常に記録紙と摩擦しているか ら, 摩耗に対してすぐれているととあに，記録紙に摩擦 帯電を与えないものでなければならない.

\section{5. 実 験 管}

ターゲット基板は解像度，記録速度の点で薄いほど有 利である.しかし，製造上の問題，機械的強度，気密性 の問題があるので, 約 $180 \mu \mathrm{m}$ の半導体ガラスを使用し

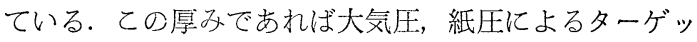
ト基板の破損は問題にならない. また，試作後 2 年以上 経過する記録管についても，真空度，バリウムゲッター 膜の外観など，ほとんよ゙初期の状態を維持しており，気 密性についても問題にならないものと考えている.

図 9 亿試作管の構造図を示す．電子銃は白黒テレビ用
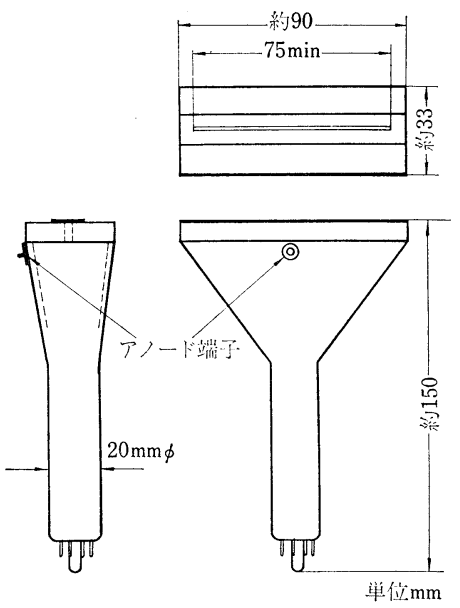

図 9 記録管の構造図

Dimension of the printing tube.

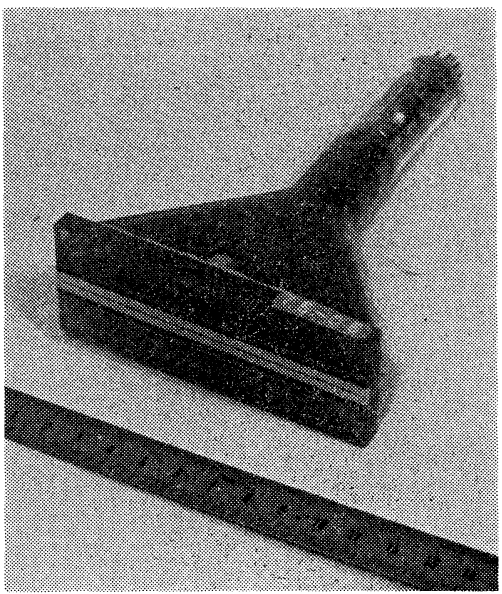

写真 1 静電記録管の外観

The exterior view of the electrostatic printing tube. 

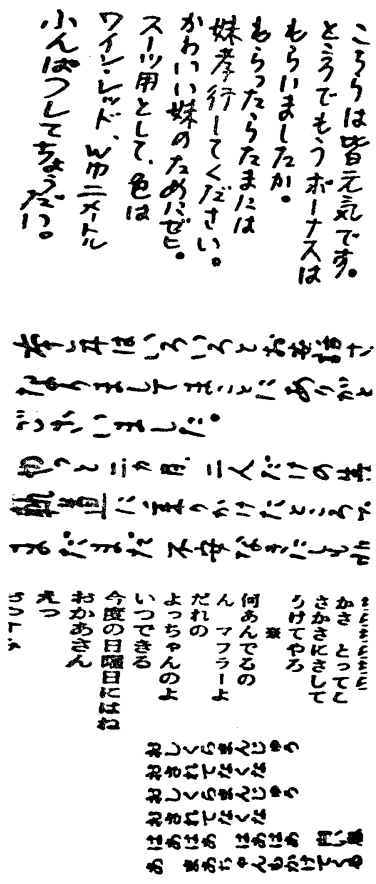

写真 2 映像記 録

Actual recorded results.

ブラウン管に使われている小型ユニポテンシャル型電子 銃をそのまま使用している。したがって高解像度は期待 できないが，調整が簡単であり，焦点樑度も梁いのでダ イナミックフォーカシングは不要である. また, ネック の直径を $20 \mathrm{~mm} \phi$ にして小型テレビ用の安価な偏向コ イルを使えるようにしている。

\section{6. 記 録 実 験}

静電記録管を用いた記録装置は，ピンチューブの場合 とほとんご同じである. 図1のようにアノードを接地 し, カソードに $-10 \mathrm{kV}$ の負高圧を印加しているので, ヒーター,グリッド，フォーカス電極は負の高圧になっ ている。

映像信号を負の高圧側にあるグリッドに印加する方法 として，フォトカップラー7)を採用した。.とれは発光ダ イオードとフォトトランジスタをガラス板をはさんで対 向させ, 映像信号を発光ダイオードに加えて光に変換 し, 負高圧側のフォトトランジスタで再び電気信号に変 換して，グリッドに印加するあのである。

偏向は水平偏向のみであるが，電子ビームの位置を調 整するために垂直方向にも直流偏向を行なっている．走
査周波数は $60 \mathrm{~Hz}$ で，映像信 号はフライングスポット管に より得ている. 写真 2 はこの 方法で映像記録を行なったす のである. 垂直方向の解像度 は $6 \sim 7$ 本 $/ \mathrm{mm}$ 程度である が，水平方向は電子銃の性能 あ影響して，てれより劣る. しかし，水亚方向の画素が連 続しているので記録画は自然 である. 写真 3 は, ビーム電 流を一定にして打き，偏向コ イルにのとぎり波電流を流し た場合の記録例である。この 場合の記録管はスリット幅を $1.0 \mathrm{~mm}$ にして抢り，記録線 幅は太くなっている。記録例 A recorded waveform. は $30 \mathrm{~Hz}$ であるが, $3 \mathrm{kHz}$ 以上の波形記録む可能である。

\section{7.むすび}

ピン電極の代りにマイクロシートガラスを記録へッド 亿使用した静電記録管の構造，動作原理，ターゲット基 板の材料などについて述べた．構造がピンチューブにく らべて簡単であるから，コストの点で有利になるものと 考えられる。

偏向周波数 $60 \mathrm{~Hz}$ における画像記録，波形記録の結果 を示したが，記録速度および解像度よりファクシミリお よび波形記録への応用などが考えられる.

終りに，本研究の遂行にあたりで指導，で協力いただ いた大阪工業技術試験所 寺井技官, 住田光学 大川氏, 当社 三戸技術本部長, 田中機構研究部長, 遠藤義明氏, 島田充浩氏および関係者に心から感謝する次第である.

(昭和 48 年 5 月 14 日受付)

\section{〔参考 文 献〕}

1) R.W. Crews, et al: The Videograph Tube-A New Component for High-Speed Printing, IRE Trans., ED-8, 5(1961) 406

2) 山下ほか：静電記録管とその諸特性, NHK 技術研究, 22, 3 (1970) 207

3）田川, 島田：静電記録管，テレビ全大 (1970)

4) 田川, 島田: 静電記録に関する一考察, 昭 45 年電気関係学会関 西支部連大

5）静電記録管用半導体ガラスの開発,大工試ニュース, No. 5(1973)

6) 田川, 猪田, 島田, 堀木, 小野瀬：静電記録管の記録へッド, テ レビ学会電子装置研凟, No. 121 (1972.10)

7) 中野, 弱野, 鈴木: 高電界に於けるホトカプラーの特性, テレビ 全大 (1972) 